\title{
ON LTB RESISTANCE ASSESSMENT OF PRISMATIC I-SECTION BEAMS ACCORDING TO EUROCODE 3
}

\begin{abstract}
The lateral-torsional buckling resistance (LTB resistance) of beams bent about the major axis is dealt in Eurocode 3 twofold: a) directly in clause 6.3.2, referring to the lateral-torsional buckling curves of the so-called General case in 6.3.2.2 and of Special case of rolled sections and equivalent welded sections in 6.3.2.3, and indirectly in 6.3 .3 as a special case of beam-columns in bending and compression (provided that the axial force and the bending moment about $z-z$ axis vanish). In the latter, interaction factors are evaluated either from Annex A (alternative method 1) or from Annex B (alternative method 2). This paper discusses the issue of interrelations of mentioned above direct and indirect approaches for the evaluation of the lateral-torsional resistance of beams under moment gradient.
\end{abstract}

Keywords: steel prismatic beams, I-section, lateral-torsional buckling, direct resistance evaluation, indirect resistance evaluation

\section{Introduction}

Part 1-1 of PN-EN 1993 [5] requires that in general situation of nonzero moment gradients of beams bent bi-axially, the following resistance utilization ratio inequity (equity as the limit) needs to be satisfied:

$$
R U R=\max \left\{R U R_{c} ; R U R_{b}\right\} \leq 1
$$

where: $R U R_{c}-$ cross-section resistance utilization ratio,

$R U R_{b}$ - beam buckling resistance utilization ratio.

The cross-section resistance utilization ratio $R U R_{c}$ is of the form:

1 Corresponding author/autor do korespondencji: Marian Giżejowski, Warsaw University of Technology, Faculty of Civil Engineering, Division of Metal Structures, Armii Ludowej 16, 00-637 Warsaw, Poland, m.gizejowski@il.pw.edu.pl

2 Zbigniew Stachura, Warsaw University of Technology, Faculty of Civil Engineering, Division of Metal Structures, Armii Ludowej 16, 00-637 Warsaw, Poland, z.stachura@il.pw.edu.pl 


$$
R U R_{c}=\left[\frac{M_{y, E d}\left(\xi_{\max }\right)}{M_{y c, R k} / \gamma_{M 0}}\right]^{\alpha}+\left[\frac{M_{z, E d}\left(\xi_{\max }\right)}{M_{z c, R k} / \gamma_{M 0}}\right]^{\beta}
$$

and the beam buckling resistance utilization ratio $R U R_{b}$ :

$$
R U R_{b}=\max \left\{\begin{array}{l}
k_{y y} \frac{M_{y, E d, \text { max }}}{M_{y b, R k} / \gamma_{M 1}}+k_{y z} \frac{M_{z, E d, \text { max }}}{M_{z c, R k} / \gamma_{M 1}} \\
k_{z y} \frac{M_{y, E d, \max }}{M_{y b, R k} / \gamma_{M 1}}+k_{z z} \frac{M_{z, E d, \max }}{M_{z c, R k} / \gamma_{M 1}}
\end{array}\right.
$$

where: $\alpha_{y}, \beta$-class and cross-section dependent constants (see [5]),

$\xi_{\max }=2 x / L-$ coordinate corresponding to the most stressed beam section,

$M_{y b, R k}=\chi_{L T} M_{y c, R k}-$ characteristic lateral-torsional buckling resistance, $\chi_{L T}$ - lateral-torsional buckling reduction factor dependent upon the slenderness ratio $\bar{\lambda}_{L T}$ calculated for the actual distribution of the bending moment $M_{y, E d}(\xi)$ (i.e. taking account for the moment gradient ratio),

$M_{y c, R k}=W_{y} f_{y}$ and $M_{z c, R k}=W_{z} f_{y}-$ characteristic cross-section bending resistances,

$W_{y}$ and $W_{z}$ - cross-section class dependent modules in bending,

$\gamma_{M 0}, \gamma_{M 1}-$ partial factors for the cross section resistance and the beam buckling resistance, respectively,

$M_{y, E d \text {, max }}$ and $M_{z, E d, \max }$ - design values of the maximum moments about the $y-y$ and $z-z$ axes, respectively.

Interaction factors $k_{i j}$ (where $i, j=y, z$ ) govern in equation (3) the effects of geometric and material nonlinearity in the beam behavior as well as the effect of moment gradients for bending about the axes $y-y$ and $z-z$. These interaction factors may be evaluated according to analytical formulation presented in Annexes of [5] (see Annex A for a more accurate calculations of the so-called alternative method 1 or Annex B for the so-called alternative method 2) or the ECCS Design Manual [6]. The values of these factors were calibrated on the basis of numerical simulations $[1,4]$. As a result, the alternative method 1 is more laborious but closer to the results of finite element simulations. The alternative method 2 is less laborious but unfortunately more conservative in comparison to both the numerical simulations and the alternative method 1 predictions. National Application documents in countries implementing the Eurocodes may choose one from the mentioned above methods, e.g. the alternative method 2 is recommended in Poland [5]. 


\section{Eurocode's recommendations}

\subsection{Resistance criteria for bi-axial bending}

Table 1 summarizes the cross-section class dependent relationships for the evaluation of interaction factors in the alternative methods 1 and 2 for beams under a combined loading condition of applied support moments about the strong axis and about the weak axis. The reference lateral-torsional buckling slenderness $\bar{\lambda}_{L T, r e f}$ is calculated using the critical moment $M_{c r, 0}$ which refers to the basic case of perfect beam elastic LTB under uniform moment, i.e. to the case of $\psi_{y}=1,0$ (where $\psi_{y}=M_{y, E d, \min } / M_{y, E d \text {, max }}$ is the support moments ratio and $M_{y, E d, \operatorname{mim}}, M_{y, E d, \max }$ are minimum and maximum support moment, respectively). One has to note that for moment gradient cases the following relationships hold:

$$
\begin{aligned}
& \bar{\lambda}_{L T}=\sqrt{\frac{M_{y c, R k}}{M_{c r}}}=\frac{\bar{\lambda}_{L T, r e f}}{\sqrt{C_{1}}}, \quad \bar{\lambda}_{L T, r e f}=\sqrt{\frac{M_{y c, R k}}{M_{c r, 0}}} \\
& M_{c r, 0}=i_{C} \sqrt{N_{c r, z} N_{c r, T}}=\frac{i_{C} N_{c, R k}}{\bar{\lambda}_{z} \bar{\lambda}_{T}}
\end{aligned}
$$

where: $C_{1}$ - critical moment modification factor that depends upon the moment gradient ratio for bending about $y-y$ axis, $M_{c r}$ - critical moment for the moment gradient case,

$M_{c r, 0}$ - critical moment for the uniform bending (the reference case), $i_{C}-$ polar radius of gyration,

$N_{c r, z}$ and $N_{c r, T}$ - flexural and torsional critical loads evaluated with use of the buckling length factors $k_{z}=k_{w}=1$,

$N_{c, R k}$ - cross section resistance in compression,

$M_{y c, R k}$ - cross section resistance in bending about $y-y$ axis,

and the other symbols according to [6].

The ratio between the critical moments $M_{c r}$ and $M_{c r, 0}$ gives the constant $C_{1}$ that may expressed for the cases of moment gradient by the following relationship [2]:

$$
C_{1}=\frac{M_{c r}}{M_{c r, 0}}=\frac{1}{\left(\frac{1+\psi_{y}}{2}\right) \frac{1}{C_{1, s}}+\frac{1}{2}\left(\frac{1-\psi_{y}}{2}\right)^{3} \frac{1}{C_{1, a}}}
$$

Where: $C_{1, s}=1,0, C_{1, a}=1,32$. 
The relationships valid for the interaction factors $k_{i j}(i, j=y, z)$ of the alternative method 1 are more detailed than those in the alternative method 2 since dependent upon more parameters influencing the shape of buckling resistance interaction curves and their numerical values. In the alternative method 2, the interaction factors depend only on the equivalent uniform moment factors $C_{m y}$ and $C_{m z}$ (see cells shown at the darker background in Table 1).

The application of alternative method 2 may lead to a different safety assessment than the application of alternative method 1. Equation (3) becomes then very conservative and for the class 3 and 4 it may be written down in the following form:

$$
R U R_{b}=\max \left\{\begin{array}{l}
\frac{M_{y, E d, e q}}{M_{y b, R k} / \gamma_{M 1}}+\frac{M_{z, E d, e q}}{M_{z c, R k} / \gamma_{M 1}} \\
\frac{M_{y, E d, \max }}{M_{y b, R k} / \gamma_{M 1}}+\frac{M_{z, E d, e q}}{M_{z c, R k} / \gamma_{M 1}}
\end{array}\right.
$$

where: $M_{y, E d, e q}=C_{m y} M_{y, E d, \max }, \quad M_{z, E d, e q}=C_{m z} M_{z, E d, \max }-$ equivalent uniform moments about section axes $y-y$ and $z-z$, respectively and other symbols conform with [5] and the ECCS Design Manual [6].

Table 1. Interaction coefficients

Tabela 1. Współczynniki interakcji

\begin{tabular}{|c|c|c|c|c|}
\hline $\begin{array}{c}\text { Interaction } \\
\text { coefficients } \boldsymbol{k}_{i j}\end{array}$ & Method 1 & Method 2 & Method 1 & Method 2 \\
\hline \multirow{2}{*}{$k_{y y}$} & $\frac{C_{m y} C_{m L T}}{C_{y y}}$ & $C_{m y}$ & $C_{m y} C_{m L T}$ & $C_{m y}$ \\
\hline$k_{y z}$ & $0,6 \sqrt{\frac{w_{z}}{w_{y}}} \frac{C_{m z}}{C_{y z}}$ & $0,6 C_{m z}$ & $C_{m z}$ & $C_{m z}$ \\
\hline$k_{z y}$ & $0,6 \sqrt{\frac{w_{y}}{w_{z}}} \frac{C_{m y} C_{m L T}}{C_{z y}}$ & $\begin{array}{c}1,0 \text { for } \bar{\lambda}_{z} \geq 0,4 \\
0,6+\bar{\lambda}_{z} \text { for } \bar{\lambda}_{z}<0,4\end{array}$ & $C_{m y} C_{m L T}$ & 1,0 \\
\hline$k_{z z}$ & $\frac{C_{m z}}{C_{z z}}$ & $C_{m z}$ & $C_{m z}$ & $C_{m z}$ \\
\hline
\end{tabular}


Explanation of variables used in Table 1.:

- alternative method 1:

$$
\begin{aligned}
& w_{y}=\frac{W_{p l, y}}{W_{e l, y}} \leq 1,5, \quad w_{z}=\frac{W_{p l, z}}{W_{e l, z}} \leq 1,5, \\
& C_{y y}=1-\left(w_{y}-1\right) b_{L T} \geq \frac{W_{e l, y}}{W_{p l, y}}, \quad C_{y z}=1-\left(w_{z}-1\right) c_{L T} \geq 0,6 \frac{W_{e l, z}}{W_{p l, z}} \sqrt{\frac{w_{z}}{w_{y}}}, \\
& C_{z y}=1-\left(w_{y}-1\right) d_{L T} \geq 0,6 \frac{W_{e l, y}}{W_{p l, y}} \sqrt{\frac{w_{y}}{w_{z}}}, \quad C_{z z}=1, \\
& a_{L T}=1-\frac{I_{T}}{I_{y}} \geq 0, \bar{\lambda}_{L T, r e f}=\sqrt{\frac{M_{y c, R k}}{M_{c r, 0}}}, \\
& b_{L T}=0,5 a_{L T} \bar{\lambda}_{L T, r e f}^{2} \frac{M_{y, E d}}{\chi_{L T} M_{p l, y, R d}} \frac{M_{z, E d}}{M_{p l, z, R d}}, \\
& c_{L T}=10 a_{L T} \frac{\bar{\lambda}_{L T, r e f}^{2}}{5+\bar{\lambda}_{z}^{4}} \frac{M_{y, E d}}{\chi_{L T} C_{m y} M_{p l, y, R d}}, \\
& d_{L T}=2 a_{L T} \frac{\bar{\lambda}_{L T, r e f}}{0,1+\bar{\lambda}_{z}^{4}} \frac{M_{y, E d}}{\chi_{L T} C_{m y} M_{p l, y, R d}} \frac{M_{z, E d}}{C_{m z} M_{p l, z, R d}}, \\
& e_{L T}=1,7 a_{L T} \frac{\bar{\lambda}_{L T, r e f}}{0,1+\bar{\lambda}_{z}^{4}} \frac{M_{y, E d}}{\chi_{L T} C_{m y} M_{p l, y, R d}} \text {, } \\
& C_{m y}=\left\{\begin{array}{cc}
0,79+0,21 \psi_{y} & \text { for } \bar{\lambda}_{L T, r e f} \leq \bar{\lambda}_{L T, 0} \\
1,0 & \text { for } \quad \bar{\lambda}_{L T, r e f}>\bar{\lambda}_{L T, 0}
\end{array}, \quad \bar{\lambda}_{L T, 0}=0,2\left(1,33-0,33 \psi_{y}\right)\right. \\
& C_{m L T}=1,0, C_{m z}=0,79+0,21 \psi_{z} \text {. }
\end{aligned}
$$

- alternative method 2:

$$
C_{m y}=0,6+0,4 \psi_{y} \geq 0,4, \quad C_{m z}=0,6+0,4 \psi_{z} \geq 0,4,
$$

and other symbols according to $[5,6]$.

\subsection{Resistance criteria for mono-axial bending about $y$ - $y$ axis}

One may expect that the safety assessment criterion of beams under monoaxial bending would yield from a special case of bi-axial bending. Letting $M_{z, E d}=0$ in equations presented in the previous subsection, the maximum dimensionless moment for rolled $\mathrm{I}$ or $\mathrm{H}$ sections, yielding either from the clauses for mono-axial bending 6.3.2.2 and 6.3.2.3 of EN 1993-1-1 [5] and for 
bi-axial bending being the simplifications of the more general interaction resistance criteria according to clause 6.3 .3 of the same code is calculated as follows:

- from the clause 6.3.2 [5] for mono-axial bending (denoted hereafter as the curve 0 ):

$$
m_{y, E d, \max }=\chi_{L T}
$$

- from the clause 6.3.3 [5] for bi-axial bending, Appendix A for the alternative method 1 (denoted hereafter as the curve 1):

$$
m_{y, E d, \max }=\left\{\begin{array}{cc}
\chi_{L T} & \text { for } \bar{\lambda}_{L T, \text { ref }}>\bar{\lambda}_{L T, 0} \\
\chi_{L T} /\left(0,79+0,21 \psi_{y}\right) & \text { for } \bar{\lambda}_{L T, \text { ref }} \leq \bar{\lambda}_{L T, 0}
\end{array}\right.
$$

- from the clause 6.3.3 [5] for bi-axial bending, Appendix B for the alternative method 2 (denoted hereafter as the curve 2):

$$
m_{y, E d, \max }=\left\{\begin{array}{cc}
\chi_{L T} & \text { for } \bar{\lambda}_{z} \geq 0,4 \\
\chi_{L T} /\left(0,6+\bar{\lambda}_{z}\right) & \text { for } \bar{\lambda}_{z}<0,4
\end{array}\right.
$$

where: $m_{y, E d, \max }=M_{y, E d, \max } / M_{y c, R k}-$ dimensionless maximum design moment about $y-y$ axis,

\section{Comparison of LT buckling resistances in case of mono-axial bending}

Figures 1. and 2. show the differences in the resistance assessment evaluated according to equations (6)-(8), i.e. yielding directly for the clause 6.3.2 [5] (either 6.3.2.2 or 6.3.3.3) of mono-axial bending and indirectly from the clause 6.3.3 [5] of bi-axial bending and compression (for $N_{E d}=0$ and $M_{z, E d}=0$ ). The comparison is made for HEB 300 section and the unit values of partial factors, i.e. for $\gamma_{M 0}=\gamma_{M 1}=1$, as well as for different values of the moment gradient ratio, namely $\psi_{y}=1,0$, and -1 , using the relevant LT buckling curves. The ordinate is the dimensionless resistance $m_{y, E d \text {, max }}$ and the abscissa is the slenderness ratio $\bar{\lambda}_{L T \text {, ref }}$. Each figure shows three curves, namely: 0 - curve from the direct use of LT buckling in mono-axial bending about $y-y$ axis, 1 - curve based on bi-axial bending verification according to the alternative method 1 and finally 2 - curve based on bi-axial bending verification according to the alternative method 2.

It is worthy to note that different LT buckling curves need to be considered for using the clauses either 6.3.2.2 or 6.3.3.3 (with imperfection factors relevant to HEB 300, namely $\alpha_{L T}=0,21$ and $\alpha_{L T}=0,34$, respectively). 
a)

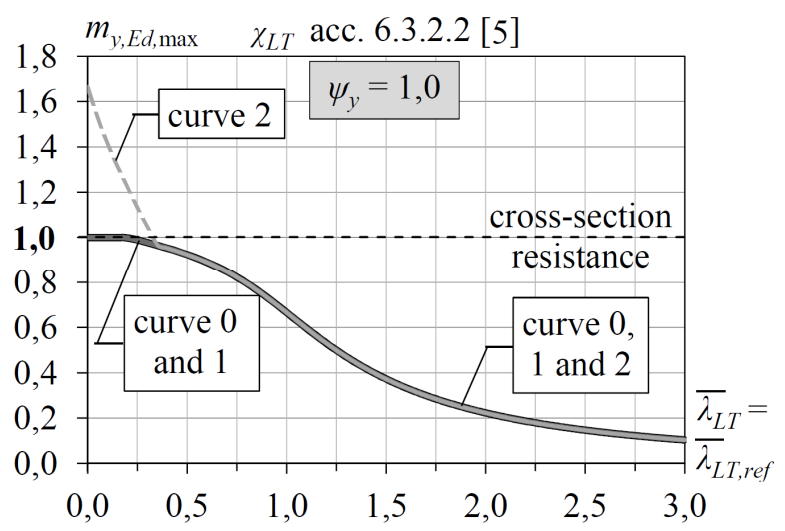

b)

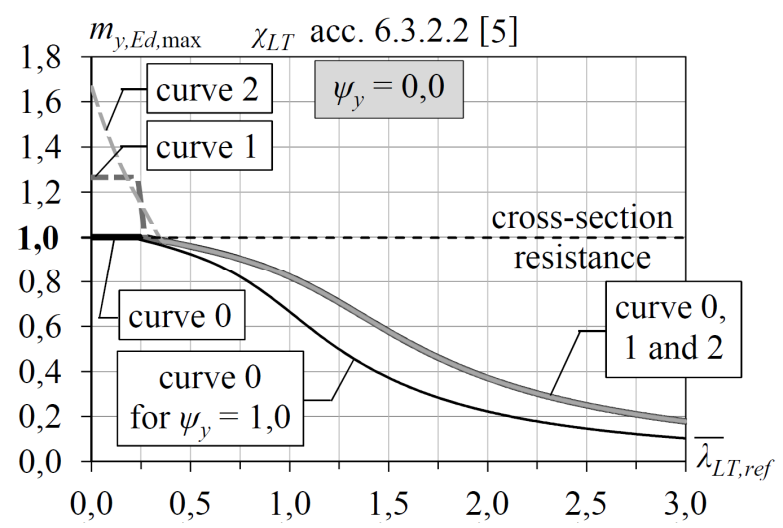

c)

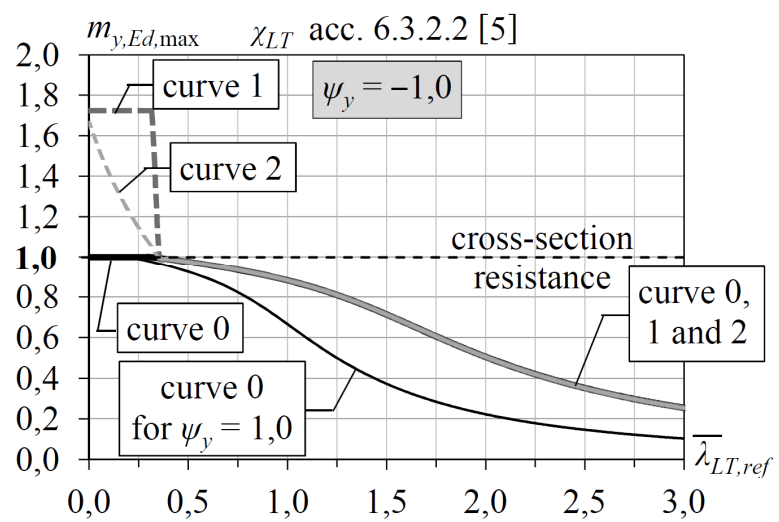

Fig. 1. Comparison of LT buckling resistance curves according to 6.3.2.2 and 6.3.3 [5], a) symmetric bending $\psi_{y}=1$, b) asymmetric bending $\left.\psi_{y}=0, \mathrm{c}\right)$ anti-symmetric bending $\psi_{y}=-1$

Rys. 1. Porównanie krzywych nośności przy zwichrzeniu wg 6.3.2.2 oraz 6.3.3 [5], a) zginanie symetryczne $\psi_{y}=1$, b) zginanie asymetryczne $\psi_{y}=0$, c) zginanie antysymetryczne $\psi_{y}=-1$ 
a)

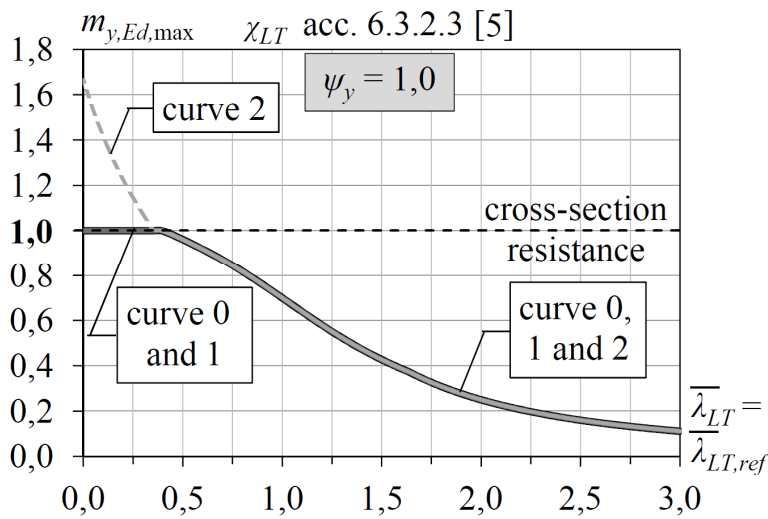

b)

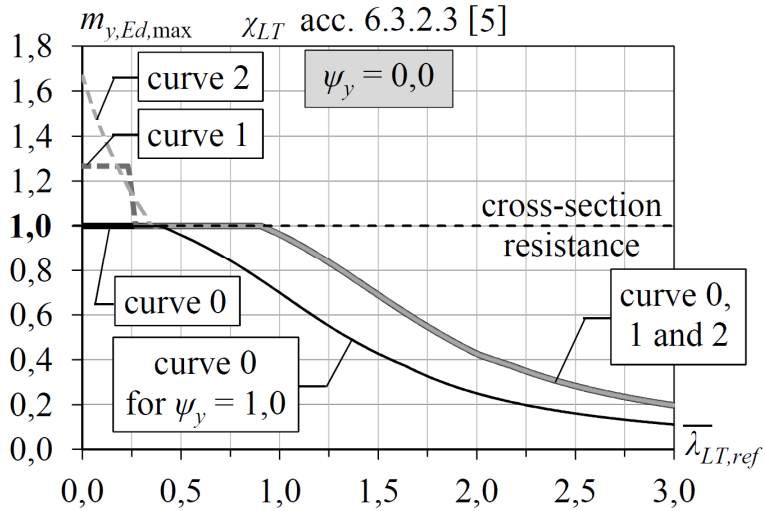

c)

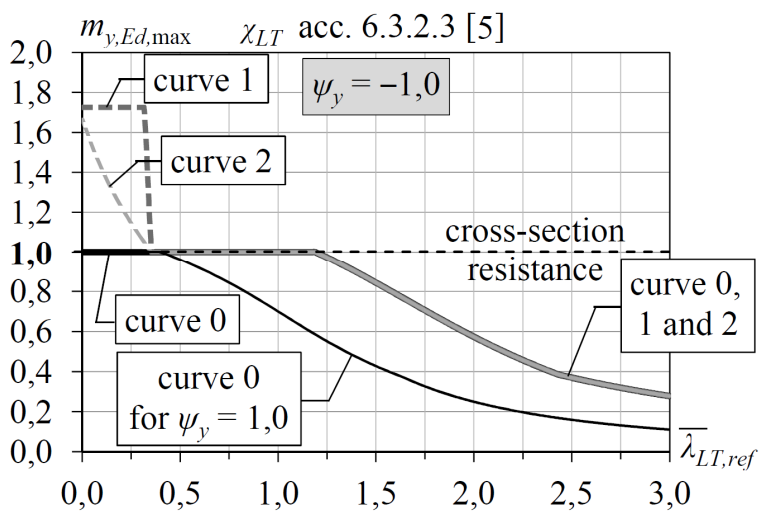

Fig. 2. Comparison of LT buckling resistance curves according to 6.3.2.3 and 6.3.3 [5], a) symmetric bending $\psi_{y}=1$, b) asymmetric bending $\left.\psi_{y}=0, \mathrm{c}\right)$ anti-symmetric bending $\psi_{y}=-1$

Rys. 2. Porównanie krzywych nośności przy zwichrzeniu wg 6.3.2.3 oraz 6.3.3 [5], a) zginanie symetryczne $\psi_{y}=1$, b) zginanie asymetryczne $\psi_{y}=0, \mathrm{c}$ ) zginanie antysymetryczne $\psi_{y}=-1$ 


\section{Conclusions}

1) Regardless the moment gradient $\psi_{y}$, for the slenderness $\bar{\lambda}_{z} \geq 0,4$ in reference to the alternative method 2 and for the slenderness $\bar{\lambda}_{L T, \text { ref }}>\bar{\lambda}_{L T, 0}=0,2\left(1,33-0,33 \psi_{y}\right)$ in reference to the alternative method 1 , the LT buckling resistance $m_{y b, R d}=M_{y b, E d} / M_{y c, R d}$ evaluated from bi-axial bending according to the clause 6.3.3 [5] coincides with that of the clause 6.3.2 of [5], namely $m_{y, E d, \max }=\chi_{L T}$ according to the General case of the clause 6.3.2.2 [5] or $m_{y, E d, \max }=\chi_{L T, \text { mod }}$ according to the Special case of the clause 6.3.2.3 [5] for rolled sections and their welded counterparts.

2) For the slenderness $\bar{\lambda}_{z}<0,4$ in reference to the alternative method 2 and $\bar{\lambda}_{L T, \text { ref }} \leq \bar{\lambda}_{L T, 0}=0,2\left(1,33-0,33 \psi_{y}\right)$ in reference to the alternative method 1 , both methods overestimate the LTB resistance according to 6.3.2 [5], except for the alternative method 1 in case of uniform bending $\left(\psi_{y}=1\right)$. The LT buckling resistance is therefore bounded by the section resistance. One has to note that for $\bar{\lambda}_{L T, \text { ref }}=\bar{\lambda}_{L T, 0}=0,2\left(1,33-0,33 \psi_{y}\right)$ there is a discontinuity in the resistance curve evaluated by the alternative method 1 .

3) Comparing the results from the General case approach (clause 6.3.2.2 [5]) and from the Special case of clause 6.3.2.3 of PN-EN 1993-1-1 [5] for rolled I and $\mathrm{H}$ sections and their welded counterparts, the latter return higher LT buckling resistances with the difference rising in course of the greater moment gradient (smaller value of the moment gradient ratio).

4) In case of anti-symmetrical moment diagram $\left(\psi_{y}=-1\right)$ and the range of practical length of beams $\left(\bar{\lambda}_{L T, \text { ref }} \leq 1,2\right), \chi_{L T}=\chi_{L T \text {,mod }}$ according to the clause 6.3.2.3 [5] overestimates the unit value, therefore the beam must be regarded as an insensitive one to LT buckling.

5) Observed differences in the LT buckling resistances $M_{y b, R d}$ evaluated for moment gradient cases from different options available in [5] indicate that there is a need for the further study with use of finite element simulations using the modeling technique presented in [3] and for the verification of Eurocode's analytical formulations applied to rolled and equivalent welded I and $\mathrm{H}$ section beams.

\section{References}

[1] Boissonnade A., Jaspart J.-P., Muzeau J.-P., Villette M.: New interaction formulae for beam-columns in Eurocode 3: The French-Belgian approach, Journal of Constructional Steel Research 60 (2004), pp. 421-431.

[2] Gizejowski M.A., Stachura Z., Uziak J.: Elastic flexural-torsional buckling of beams and beam-columns as a basis for stability design of members with discrete rigid 
restraints. In: Insights and Innovations in Structural Engineering, Mechanics and Computation (ed. A. Zingoni), London, Taylor \& Francis Group 2016, pp. 261-262, e-book on CD, pp. 738-744.

[3] Gizejowski M.A., Stachura Z., Szczerba R.B., Gajewski M.D.: Numerical study of buckling resistance of steel I-section members. In: Insights and Innovations in Structural Engineering, Mechanics and Computation (ed. A. Zingoni), London, Taylor \& Francis Group 2016, pp. 267-268, e-book on CD, pp. 758-763.

[4] Greiner R., Lindner J.: Interaction formulae for members subjected to bending and axial compression in Eurocode 3 - the Method 2 approach, Journal of Constructional Steel Research 62 (2006), pp. 757-770.

[5] PN-EN 1993-1-1:2005, Eurocode 3: Design of steel structures - Part 1-1: General Rules and Rules for Buildings, CEN, Brussels 2005 (in Polish).

[6] Simoes da Silva L., Simoes R., Gervasio H.: Design of Steel Structures, Eurocode 3: Design of Steel Structures, Part 1-1: General Rules and Rules for Buildings ( $2^{\text {nd }}$ edition), ECCS Eurocode Design Manual, Ernst \& Sohn, Berlin 2010.

\title{
W SPRAWIE OCENY NOŚNOŚCI NA ZWICHRZENIE PRYZMATYCZNYCH BELEK O PRZEKROJACH DWUTEOWYCH ZGODNIE Z EUROKODEM 3
}

\begin{abstract}
Streszczenie
Nośność na zwichrzenie belek zginanych względem osi większej bezwładności przekroju można określić na podstawie normy PN-EN 1993-1-1 na dwa sposoby: a) bezpośrednio na podstawie punktu 6.3.2 ww. normy, przyjmując współczynnik redukcyjny $\chi_{L T}$ zgodnie z postanowieniami przypadku ogólnego (podpunkt 6.3.2.2) lub zmodyfikowany współczynnik

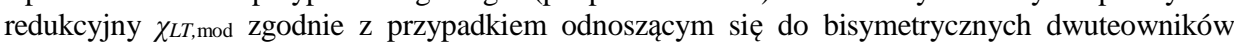
walcowanych i ich odpowiedników spawanych (podpunkt 6.3.2.3); b) pośrednio na podstawie punktu 6.3.3 ww. normy, rozpatrując szczególny przypadek elementu ściskanego i zginanego, w którym zanika wpływ ściskania i zginania względem osi mniejszej bezwładności. W odniesieniu do metody pośredniej wg 6.3.3 normy, współczynniki interakcji można wyznaczyć na podstawie Załącznika A (alternatywna metoda 1) lub Załącznika B (alternatywna metoda 2) ww. normy. $\mathrm{W}$ artykule przeprowadzono dyskusję wzajemnych relacji pomiędzy przedstawionym podejściem bezpośrednim i pośrednim w wyznaczaniu nośności belek zginanych narażonych na zwichrzenie. Na przykładzie swobodnie podpartej belki zginanej dwoma momentami podporowymi o różnym znaku i wartości porównano powyższe podejścia i sformułowano wnioski.
\end{abstract}

Słowa kluczowe: stalowe belki pryzmatyczne, dwuteownik, zwichrzenie, bezpośrednia ocena nośności, pośrednia ocena nośności

Przestano do redakcji: 11.04.2017 r.

Przyjęto do druku: 01.09.2017 r. 